\title{
Dichotomous branching: the plant form and integrity upon the apical meristem bifurcation
}

\section{Edyta M. Gola*}

Department of Plant Developmental Biology, Institute of Experimental Biology, University of Wrocław, Wrocław, Poland

\author{
Edited by: \\ Jochem B. Evers, Wageningen \\ University and Research Centre, \\ Netherlands \\ Reviewed by: \\ Philip Brewer, The University of \\ Queensland, Australia \\ Elzbieta Zenkteler, Adam Mickiewicz \\ University, Poland \\ *Correspondence: \\ Edyta M. Gola, Department of Plant \\ Developmental Biology, Institute of \\ Experimental Biology, University of \\ Wroctaw, Kanonia 6/8, 50-328 \\ Wroctaw, Poland \\ e-mail:edyta.gola@uni.wroc.pl
}

The division of the apical meristem into two independently functioning axes is defined as dichotomous branching. This type of branching typically occurs in non-vascular and nonseed vascular plants, whereas in seed plants it presents a primary growth form only in several taxa. Dichotomy is a complex process, which requires a re-organization of the meristem structure and causes changes in the apex geometry and activity. However, the mechanisms governing the repetitive apex divisions are hardly known. Here, an overview of dichotomous branching is presented, occurring in structurally different apices of phylogenetically distant plants, and in various organs (e.g., shoots, roots, rhizophores). Additionally, morphogenetic effects of dichotomy are reviewed, including its impact on organogenesis and mechanical constraints. At the end, the hormonal and genetic regulation of the dichotomous branching is discussed.

Keywords: dichotomy, terminal branching, apical cell, apical meristems, meristem bifurcation

\section{INTRODUCTION}

Regular branching allows plants to expand and adapt to the environment. There are two major types of shoot branching: lateral (axillary), which involves the formation of a primordial bud in the organogenic zone of the apex, and terminal (dichotomous), which is an outcome of the meristem bifurcation. Root branching is mostly related to the initiation of lateral roots in the pericycle or endodermis and only in some plant groups it is a result of a dichotomous division (Evert, 2006). The most common and also the best-studied are axillary shoot branching and lateral root formation, and not much attention is paid to dichotomy, which requires the drastic reorganization of the entire meristem, while not disrupting its integrity upon the division, and as such it has to be tightly controlled. Thus, revealing the mechanisms employed to protect the meristem integrity and function, especially in the actively dividing apices, is extremely interesting. So far the research was mostly focused on the anatomy of dichotomizing apices but the regulation of this underestimated phenomenon requires the elucidation.

\section{DEFINITION OF DICHOTOMY}

Dichotomy means division into two parts and mostly refers to the bifurcation of thalli and axial organs (shoots, roots), giving rise to two morphologically similar yet autonomous parts. Although dichotomy seems to be intuitively easy to define in terms of external morphology, its development and the proper classification are not always clear. In addition, it is present in various plant groups, which differ in the internal organization of growing points (meristems), where the branching is initiated. Accordingly, the definitions of dichotomy and mechanisms involved in the meristem division reflect these structural varieties.
Generally, the apical meristem can consist of one morphologically distinct apical cell (AC), localized at the summit of the meristem, which divisional activity produces all cells and tissues (Evert, 2006). The dichotomy here is defined in a narrow sense as an equal longitudinal division of this single $\mathrm{AC}$, where both derivative cells become the initials for twin apices (Goebel, 1928; Troll, 1937; Schoute, 1938; Bierhorst, 1977). Alternatively, the meristem comprises of one or more groups of morphologically similar initial cells and their youngest derivatives (Evert, 2006). The dichotomy is understood here in a broad sense, as an equal division of the initial zone of such meristems, including initial cells and organizing center (Steeves and Sussex, 1989). This definition of dichotomy is however, often applied also to the meristems with a single AC (Hagemann and Schulz, 1978; Hagemann, 1980).

\section{MECHANISM OF DICHOTOMOUS BRANCHING}

Structural analyses of dichotomizing apices showed that dichotomy can proceed according to different developmental patterns. In the meristems with a single $\mathrm{AC}$ it can be a: (1) direct division of the AC, (2) formation of a new branch near the original $\mathrm{AC}$, which remains active in the second branch, and (3) inactivation of the original $\mathrm{AC}$ with the simultaneous initiation of the new branch initials. In plants with two ACs, dichotomy is related to repeated divisions of initials (4). In meristems containing one or more groups of initial cells, the entire meristem divides to form dichotomous apices (5).

\section{DIRECT DIVISION OF AN AC (FIGURE 1A, TABLE 1)}

The classical example of dichotomy in a narrow sense, caused by an even longitudinal division of the $\mathrm{AC}$, is a thallus bifurcation in an alga Dictyota dichotoma (Oltmanns, 1889; Goebel, 1928; van den Hoek et al., 1995). However, in most plant species with a single $\mathrm{AC}$, this tetrahedral, lens- or wedge-shaped AC rarely undergoes 


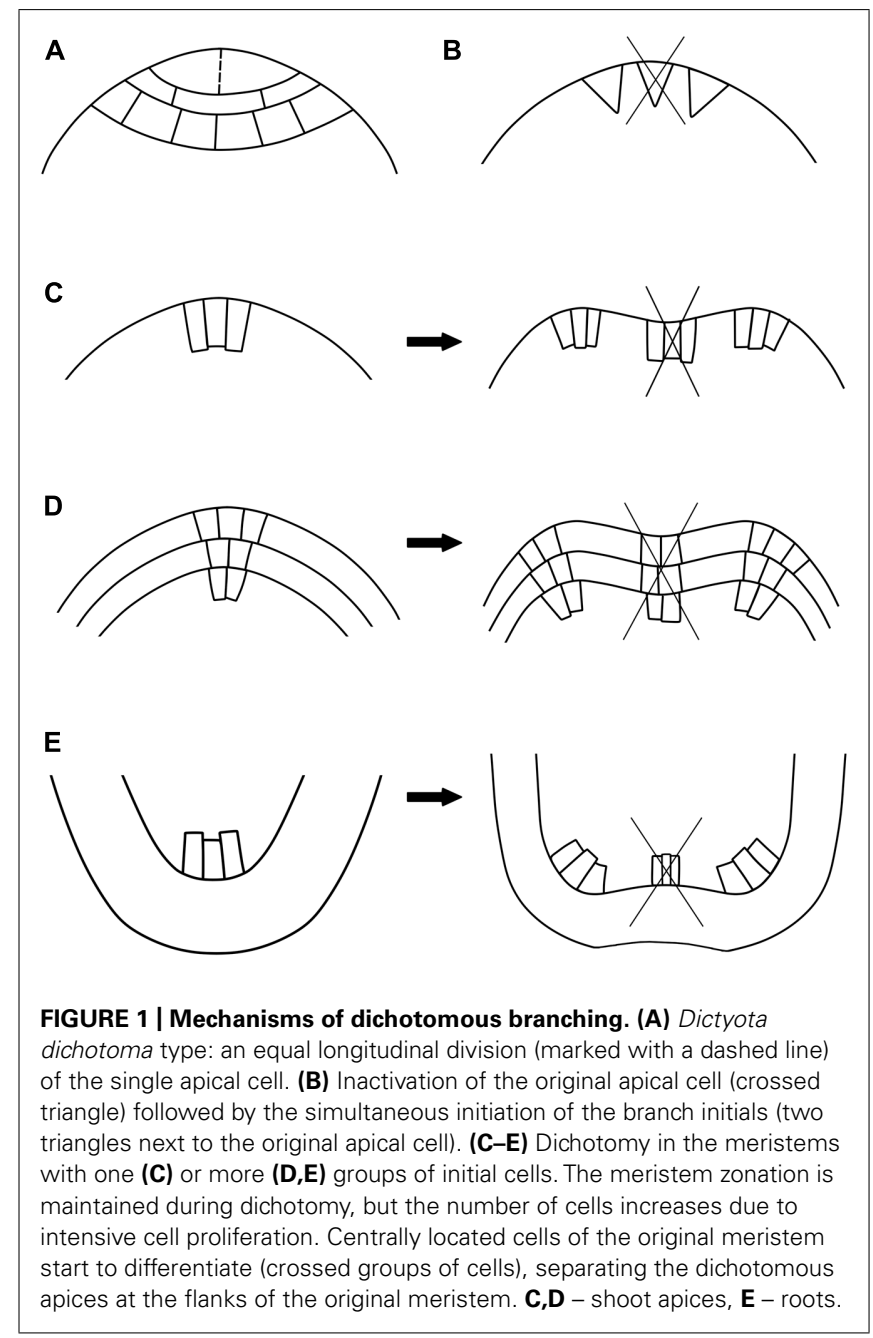

a perfect longitudinal division, probably due to the reduction of the energy costs related to the new cell wall insertion during cell division (Schüepp, 1966; Cooke and Paolillo, 1980; Barlow, 1992). As a consequence, direct division of the $\mathrm{AC}$ is uncommon. It was reported to occur only in some ferns (Bierhorst, 1977). But even this interpretation was later criticized, mostly because the ACs for the new branches originated by formative divisions and not by a direct dissection of the AC (see Lyndon, 1998 for discussion).

\section{ORIGINAL AC BECOMES AN INITIAL FOR A BRANCH (TABLE 1)}

In this pattern, the initial for a new branch originates not by the split of the original AC, but due to formative division in the adjacent segment. At the same time, the original $\mathrm{AC}$ maintains the growth of the main axis. Thus, it should be considered the pseudodichotomy (Schuster, 1984a), meaning that even if it looks like dichotomy, it is not formed by the meristem division. Such a branch development was described in detail in thalloid liverworts (Schuster, 1984a); in Psilotum nudum it was interpreted as dichotomy (Roth, 1963).

\section{INACTIVATION OF THE ORIGINAL AC FOLLOWED BY THE INITIATION OF BRANCH INITIALS (FIGURE 1B, TABLE 1)}

Dichotomy in a broad sense is applied here, understood as the division of the whole initial zone. The AC, which is usually distinct in non-dividing shoots, ceases its divisional activity prior to dichotomy and becomes indistinguishable at the apex. Then, two new initials are simultaneously initiated next to the inactivated original AC (Hagemann and Schulz, 1978; Hagemann, 1980; Mueller, 1982; Steeves and Sussex, 1989; Imaichi and Kato, 1991; Jernstedt etal., 1994; White and Turner, 1995; Lu and Jernstedt, 1996; Kato and Imaichi, 1997; Imaichi, 2008). This type of dichotomy occurs in shoots, rhizomes and roots, in some ferns and lycophytes (Table 1). In details, the changes of the meristem structure were analyzed in the rhizophores the unique axial organs of Selaginella, bearing the root primordia at the tip (Imaichi and Kato, 1989, 1991; Jernstedt et al., 1994; Lu and Jernstedt, 1996; Kato and Imaichi, 1997). Such a dichotomy occurs also in the aerial shoots of Psilotum nudum, whereas in irregularly branched subterranean rhizomes, numerous ACs present at the apex can at random be selected for new branches or be inactivated. The mechanism differentiating the fate of ACs in the shoot and rhizome is not known (Takiguchi et al., 1997).

\section{INTENSIVE DIVISIONS OF TWO ACS FOLLOWED BY THE SELECTION OF BRANCH INITIALS (TABLE 1).}

In shoots of Selaginella kraussiana two transient ACs are responsible for the apex growth. Here, before dichotomous branching the initial cells divide several times, producing a group of meristematic cells. Then, new ACs are selected for the two resulting axes (Harrison et al., 2007). Possibly, a similar branching pattern is also present in the notch meristems of Anthoceros, where intensive divisions of prismatic initial(s) result in a group of meristematic cells, which next split to form the furcated lobes (Schuster, 1984b).

\section{DICHOTOMY IN MERISTEMS WITH MULTIPLE INITIAL CELLS - SPLIT OF THE ENTIRE MERISTEM (FIGURES 1C-E, TABLE 1)}

This mechanism is typical of Lycopodiaceae s.l., where the entire meristem can divide into two even (isotomy) or uneven (anisotomy) parts (Figure 1C; Troll, 1937, 1948; Schoute, 1938; Øllgaard, 1979, 1990). In seed plants, dichotomy rarely occurs in gymnosperm shoots (Riding, 1976; Zagórska-Marek, 1985). However, the potential to branch dichotomously is preserved in conifers, as after colonization by mycorrhizal fungi, the lateral roots start to bifurcate (Figure 1E; Robertson, 1954; Wilcox, 1968; Faye etal., 1981; Piche etal., 1982). In angiosperms, shoot dichotomy is reported as a typical branching pattern only in several species, mostly in monocotyledons (Figure 1D).

Regardless of the structural differences related to the type of organ and organization of its meristem, the morphogenetic processes that accompany the branching are similar in all these plant groups. Dichotomy affects the apex geometry, forces the reorganization of the meristem structure, changes its divisional activity and cell differentiation, and has an impact on organogenesis (e.g., leaf initiation). Its first symptom is broadening of the apex in 
Table 1 | A list of plant species characterized by dichotomous branching.

\section{Plants}

\section{Reference and comments}

1. Direct division of an apical cell

Dictyota dichotoma (Phaeophyta)

Oltmanns (1889, 1904), Goebel (1928), van den Hoek etal. (1995)

Dennstaedtia and Microlepia (ferns)

White and Turner (1995)

\section{Original AC maintained, becomes an initial for a branch - pseudodichotomous branching}

Psilotum nudum

Metzgeriales, Jungermanniales Roth (1963): aerial stems; interpreted as dichotomy

Schuster (1984a): pseudodichotomy

(liverworts)

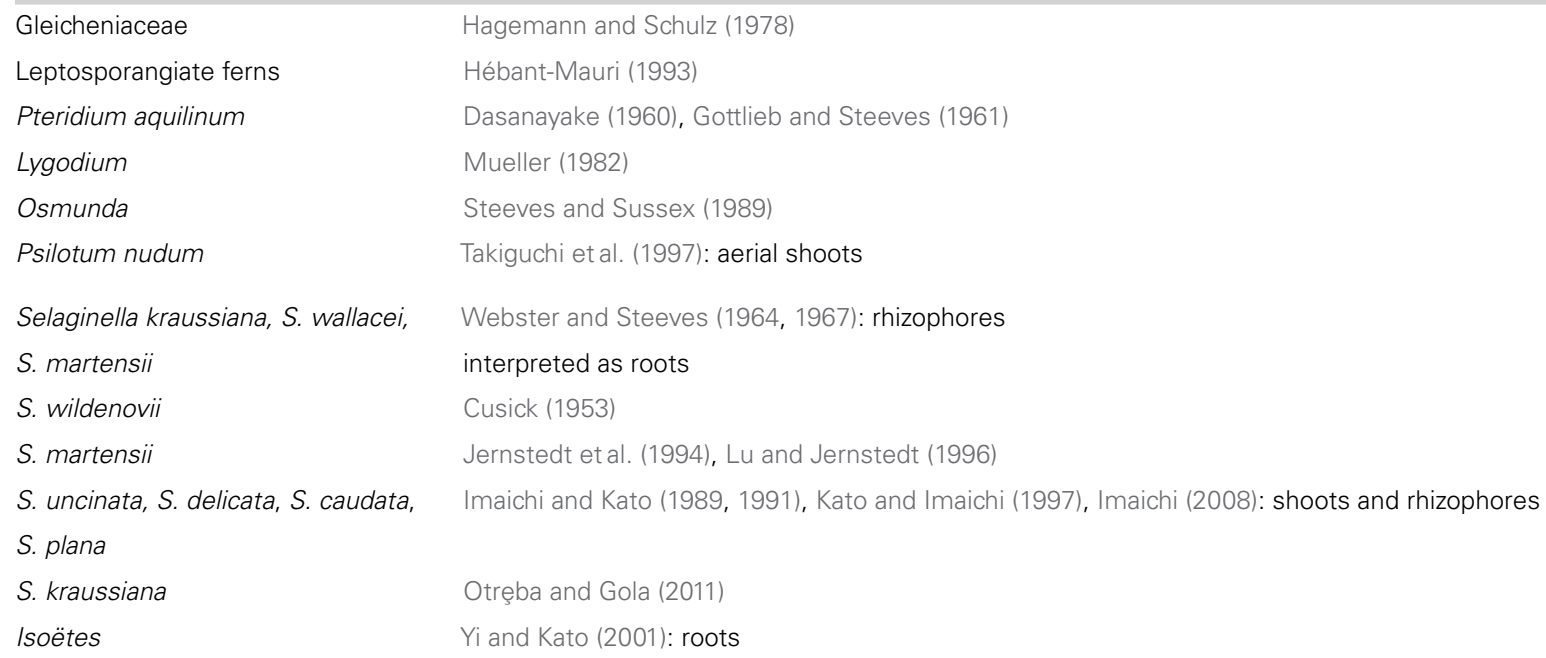

4. Intensive divisions of one or two ACs

Selaginella kraussiana

Anthoceros

Fucus (Phaeophyta)

Harrison et al. (2007)

Schuster (1984b): formation of the dichotomously lobed thalli due to divisions of one or more prismatic initials in the notch meristem

Moss (1967): AC in the notch produces few derivatives, which form the forkation; interpreted as pseudodichotomy; van den Hoek et al. (1995): pseudodichotomy

\section{Dichotomy in meristems with multiple initial cells}

Lycopodiaceae s.I., Lycopodium,

Huperzia lucidula

Pinus radiata

Abies balsamea

Cycadaceae, Macrozamia

Pinaceae, Pinus sylvestris,

$P$. resinosa, $P$. strobus,

$P$. pineaster, $P$. radiata

Hyphaene

Nypa fruticans

Chamaedorea cataractarum

Eugeissona

Flagellaria indica

Strelitzia reginae

Asclepias syriaca

Mammillaria

Echinocereus reichenbachii

Edgeworthia chrysantha
Troll (1937, 1948), Härtel (1937), Schoute (1938), Imaichi (2008), von Guttenberg (1966), Øllgaard (1979, 1990), Gola and Jernstedt (2011)

Riding (1976): shoots, ca. $1 \%$ of seedlings

Zagórska-Marek (1985): seedlings

Ahern and Staff (1994): ectomycorrhizal roots

Ectomycorrhizal roots: Robertson (1954), Wilcox (1968), Faye etal. (1981), Wilson and Field (1984), Piche et al. (1982), Kaska et al. (1999)

Hallé et al. (1978), Tomlinson (1979)

Tomlinson (1971)

Fisher (1974)

Fisher etal. (1989): supposedly dichotomy

Tomlinson (1970), Tomlinson and Posluszny (1977)

Fisher (1976)

Nolan (1969)

Craig (1945), Boke (1976)

Boke and Ross (1978)

Iwamoto et al. (2005): trichotomy 
the plane perpendicular to the future division. In this early stage, the meristem zonation pattern is not disrupted, but the number of cells and volumes of particular meristematic zones increase by intensive cell proliferation. The distinctiveness of superficial layers is maintained during dichotomy progression, as well as the continuity of procambium and vascular tissues in the parental and dichotomous axes. Differentiation of the meristematic cells located between dichotomizing apices ceases the growth of the central part of the original meristem starting the separation of both branches (Härtel, 1937; Nolan, 1969; Tomlinson, 1970, 1971; Boke, 1976; Tomlinson and Posluszny, 1977; Faye et al., 1981; Piche et al., 1982; Laajanen et al., 2007; Raudaskoski and Salo, 2008; Gola and Jernstedt, 2011).

Broadening of the shoot apex can affect the organogenesis due to increasing size of the region of organ initiation. If the leaf initiation precedes the apex dichotomy, the leaf can encircle the enlarged stem (as in Flagellaria and Strelitzia; Tomlinson, 1970; Fisher, 1976) or be inserted in the increased meristem circumference. In the latter case, the pattern of leaf arrangement (phyllotaxis) can change (Schoute, 1938; Zagórska-Marek, 1985; Gola, 1996). With dichotomy progression, the initiation of new organs is usually maintained at the shoot circumference, but at the inner surface of furcation, organogenesis is repressed until the division is completed. It can be presumed, based on the analogy to the concave apices (Lintilhac, 2014), that this inner surface remains under the tension, which prevents the bulging of primordia. The restoration of organ initiation becomes possible after changes of the physical constraints and the local surface relaxation, similarly to the proposed buckling mechanism of leaf primordia formation (Green, 1996).

\section{REGULATORY MECHANISMS FOR DICHOTOMOUS BRANCHING}

Dichotomous branching is a complex process which requires a precise control of morphogenetic events to maintain the meristem integrity during division. The lack of such a control can lead to unbalanced cell proliferation and, e.g., result in fasciation, to which dichotomy was sometimes compared (Schoute, 1936; Gorter, 1965). Fasciation is usually characterized by flattened stems with multiplied lateral organs; the stems can split to numerous normal or malformed shoots. It is an unpredictable process, caused by various agents (e.g., mutations, chemicals, pathogens including Rhodococcus fascians), which is related to the impairment of the hormonal balance and cell proliferation at the meristem (e.g., Gorter, 1965; Leyser and Furner, 1992; Fambrini et al., 2006; Stes et al., 2013). Conversely, dichotomy is a repetitive process of strictly controlled divisions of the entire meristem. Not much is however, known about the regulatory mechanisms at the hormonal and genetic levels, mostly because dichotomy occurs in plants which are not model organisms. Relatively more information is available on the hormonal regulation of the root dichotomy in gymnosperms, due to the intensive research on mycorrhiza.

\section{HORMONAL CONTROL OF DICHOTOMOUS BRANCHING}

The ability to form dichotomous roots seems to be an inherent feature in Pinaceae (Robertson, 1954; Wilson and Field,
1984; Kaska etal., 1999). The intensification of the process, with repeated dichotomies resulting in so-called coralloid structures, is related to the colonization of roots by ectomycorrhizal fungi (Peterson and Bonfante, 1994). The fungal symbionts are probably the source of plant growth regulators, which stimulate morphogenetic changes, including root swelling and dichotomous branching (Barker and Tagu, 2000; Brundrett, 2002). Similar changes in the root architecture can be induced in the absence of fungi by exogenously supplied phytohormones or their inhibitors (Wilson and Field, 1984; Rupp et al., 1989; Kaska et al., 1999; Laajanen et al., 2007; Raudaskoski and Salo, 2008). Application of auxin transport inhibitors [ $N$-(1-naphtyl)phthalamic acid (NPA); 2,3,5-triiodobenzoic acid (TIBA)], ethylene precursor [(1-aminocyclopropane-1-carboxylic acid (ACC)], or ethylene releasing compounds [2-chloroethylphosphonic acid (CEPA)] stimulates extensive dichotomous branching of Pinus roots, increasing the percentage of coralloid structures up to $25-30 \%$ (Kaska et al., 1999). It is suggested that the balance between auxin [indole-3-acetic acid (IAA)] and cytokinin, possibly mediated by the ethylene level, has a regulatory role in this process (Rupp etal., 1989; Kaska etal., 1999; Barker and Tagu, 2000; Laajanen et al., 2007; Raudaskoski and Salo, 2008). Possibly, the NPA-treatment increases the auxin concentration at the root tip, whereas the moderate level of the hormone at the meristem flanks induces dichotomous root formation. At the same time, high IAA concentration at the root tip stimulates the biosynthesis of ethylene, leading to cell differentiation in the central part of the original meristem and consequently, separation of dichotomous roots (Laajanen et al., 2007; Raudaskoski and Salo, 2008).

This mechanism of hormonal regulation corresponds well with the morphogenetic changes in dichotomizing roots of Pinus, but because it was proposed based on the auxin distribution in a model plant Arabidopsis, it should be validated. Nevertheless, it seems likely that specific hormone distribution and/or concentration can be a universal aspect of dichotomy regulation, as e.g., auxin shapes different developmental processes in all vascular plants and bryophytes (Cooke et al., 2002). In addition, it has recently been shown that the ratio between IAA and cytokinin regulates the dichotomous root branching in S. kraussiana, although the shoot dichotomy regulation by auxin is questionable in this species (Sanders and Langdale, 2013).

\section{REGULATION OF THE APEX INTEGRITY DURING DICHOTOMY}

The knowledge concerning genetic background for dichotomy regulation and molecular signaling during this process is lacking. It can only be speculated that the regulation is based on genes involved in the cell division and differentiation homeostasis, affecting the size of the apex and the identity of meristematic cells.

The genetic machinery for the self-maintenance of the apical meristems is mostly deciphered in a model plant Arabidopsis. Here, based on the mutant phenotypes, it is possible to infer which genes could play a role in dichotomous branching. One of such Arabidopsis mutants is tonsoku (tsk), with a forked root reminiscing of dichotomy, and fasciated stems. The suggested role of tsk is to maintain the ordered structure of the meristem 
through the regulation of the cell cycle (Suzuki et al., 2004, 2005). However, the disorganization in tsk root meristems affects the expression of the other regulatory genes, e.g., SCARECROW (SCR; Suzuki et al., 2004). Contradictory, it was shown that the tissuespecific expression pattern of the SCR homolog is preserved in dichotomizing roots of Pinus. During dichotomy progression, the specificity of endodermis and root radial patterning are maintained, manifested by localization of this gene (Laajanen et al., 2007; Raudaskoski and Salo, 2008). These results are also in agreement with the cytohistological observation of dichotomizing apices.

The maintenance of the shoot apical meristem integrity in Arabidopsis requires the activity of WUSCHEL (WUS), which is antagonized by the CLAVATA genes (Laux et al., 1996; Fletcher etal., 1999; Reddy, 2008). As these genes are involved in the production and maintenance of initial cells and their mutation can result also in bifurcated stem phenotype (e.g., in clv3 or WUS overexpression mutants), their plausible role in dichotomy regulation can be therefore hypothesized. Interestingly, the homologous CLAVATA1-LIKE gene was found to play a potential role in the initiation of Pinus ectomycorrhizal roots (Heller et al., 2012). Furthermore, as recent research revealed the presence of WUS homologs in all plant groups (Lian et al., 2014) and the CLAVATA3 homolog was earlier described e.g., in Selaginella (Floyd and Bowman, 2007), the universality of the regulatory mechanism in plants can be suggested. However, it remains unknown, whether these homologous genes have a similar expression pattern and function in the apical meristem maintenance and if they are involved in dichotomy regulation.

Recently, the WUS-CLV3 interactions were simulated in the reaction-diffusion model to show different patterns of shoot apical meristem (SAM) development (Fujita et al., 2011). The assumption was that WUS promotes the growth of the apex (activator) whereas CLV suppresses the process (inhibitor). The pattern of dichotomous branching was generated in this model, when the increased level of the activator stimulated the cell proliferation leading to the meristem bifurcation due to spatial restrictions (SAM size limitation; Fujita et al., 2011). Thus, it can imply that the proper balance of these two factors can play a role in the meristem integration during dichotomy.

Finally, the class I KNOX (KNOTED-like homeobox) genes are hypothesized to suppress the cell differentiation within the SAM. They are found in all land plants and, in addition, they are supposed to be regulated by hormones (Veit, 2009). For example, a low level of auxin stimulates the class I KNOX genes and in turn promotes the meristematic activity in the SAM. Likely, the formation of the new apices at the flanks of dichotomizing meristem and simultaneously triggered differentiation in its center can result from the localized distribution of auxin and related expression of genes. Furthermore, in Selaginella KNOX/ARP (ASYMMETRIC LEAVES1, ROUGH SHEATH2, PHANTASTICA) interaction regulates the maintenance of the indeterminate growth of the apex vs. leaf formation. It was suggested that this expression pattern within the SAM can be related to the meristem dichotomy (Harrison et al., 2005).

\section{CONCLUSION}

Dichotomy is only marginally studied in plants and only its anatomical aspects are relatively well described. Nevertheless even here different definitions used and the lack of molecular background leads to the misunderstandings and erroneous interpretations.

Specification of the new ACs/meristematic centers boundaries seems to be a crucial problem for dichotomy, specifically deciphering the nature of the signal(s), the site of its origin and propagation. Likely, changes in auxin distribution and its polar transport can orchestrate the boundaries specification. The cellular and/or molecular pathways of possible auxin signaling during dichotomy, as well as its interactions with other compounds, require further research and visualization.

Determination and then separation of the meristematic centers can be related to the loss of communication between the adjacent cells of dichotomizing apices. Microsurgical and ablation experiments showed that a longitudinal split of the meristem can mimic the dichotomous branching (Snow and Snow, 1931; Reinhardt et al., 2004). However, the ablation of the superficial meristem layers did not stimulate the meristem split (Reinhardt et al., 2003) suggesting the involvement of the organizing center and the meristem identity genes expressed there.

Currently, the meristem homeostasis is extensively explored, acknowledging its vital role in plant development. The improvement of the genetic and molecular techniques, also in new model organisms, e.g., Selaginella moellendorffii, will enable us to fully address the problem of the meristem integrity, especially during the meristem bifurcation.

\section{ACKNOWLEDGMENTS}

I would like to thank the colleagues from the Department of Plant Developmental Biology for the discussion and comments on the manuscript; specifically to Kasia Sokołowska, Ph.D., for help with Figure 1.

\section{REFERENCES}

Ahern, C. P., and Staff, I. A. (1994). Symbiosis in cycads: the origin and development of coralloid root in Macrozamia communis (Cycadaceae). Am. J. Bot. 81, 15591570. doi: $10.2307 / 2445333$

Barker, S. J., and Tagu, D. (2000). The roles of auxins and cytokinins in mycorrhizal symbioses. J. Plant Growth Regul. 19, 144-154. doi: 10.1007/s0034400 00021

Barlow, P. W. (1992). From cell wall networks to algorithms. The simulation and cytology of cell division patterns in plants. Protoplasma 162, 69-85. doi: 10.1007/BF02562551

Beerling, D. J., and Fleming, A. J. (2007). Zimmermann's telome theory of megaphyll leaf evolution: a molecular and cellular critique. Curr. Opin. Plant Biol. 10, 4-12. doi: 10.1016/j.pbi.2006.11.006

Bierhorst, D. W. (1977). On the stem apex, leaf initiation and early leaf ontogeny in filicalean ferns. Am. J. Bot. 64,125-152. doi: 10.2307/2442101

Boke, N. H. (1976). Dichotomous branching in Mammillaria (Cactaceae). Am. J. Bot. 63, 1380-1384. doi: 10.2307/2441846

Boke, N. H., and Ross, R. G. (1978). Fasciation and dichotomous branching in Echinocereus (Cactaceae). Am. J. Bot. 65, 522-530. doi: 10.2307/24 42585

Brundrett, M. C. (2002). Coevolution of roots and mycorrhizas of land plants. New Phytol. 154, 275-304. doi: 10.1046/j.1469-8137.2002.00397.x

Cooke, T. J., and Paolillo, D. J. (1980). The control of the orientation of cell divisions in fern gametophytes. Am. J. Bot. 67, 1320-1330. doi: 10.2307/2442134 
Cooke, T. J., Poli, D. B., Sztein, A. E., and Cohen, J. D. (2002). Evolutionary patterns in auxin action. Plant Mol. Biol. 49, 319-338. doi: 10.1023/A:10152426 27321

Craig, R. T. (1945). The Mammillaria Handbook. Pasadena: Abbey Garden Press.

Cusick, F. (1953). Experimental and analytical studies on Pteridophytes. XXII. Morphogenesis in Selaginella willdenovii Baker. I. Preliminary morphological analysis. Ann. Bot. 17, 369-383.

Dasanayake, M. D. (1960). Aspects of morphogenesis in a dorsiventral fern, Pteridium aquilinum (L.) Kuhn. Ann. Bot. 24, 317-329.

Evert, R. F. (2006). Esau's Plant Anatomy. Meristems, Cells, Tissues of the Plant Body: their Structure, Function, and Development, 3rd Edn. Hoboken, NJ: John Wiley \& Sons, Inc. doi: 10.1002/0470047380

Fambrini, M., Bonsignori, E., Rapparini, F., Cionini, G., Michelotti, V., Bertini, D., et al. (2006). Stem fasciated, a recessive mutation in sunflower (Helianthus annuus), alters plant morphology and auxin level. Ann. Bot. 98, 715-730. doi: 10.1093/aob/mc1 153

Faye, M., Rancillac, M., and David, A. (1981). Determinism of the mycorrhizogenic root formation in Pinus pinaster Sol. New Phytol. 87, 557-565. doi 10.1111/j.1469-8137.1981.tb03226.x

Fisher, J. B. (1974). Axillary and dichotomous branching in the palm Chamaedorea. Am. J. Bot. 61, 1046-1056. doi: 10.2307/2441922

Fisher, J. B. (1976). Development of dichotomous branching and axillary buds in Strelitzia (Monocotyledoneae). Can. J. Bot. 54, 578-592. doi: 10.1139/ b76-059

Fisher, J. B., Goh, C. J., and Rao, A. N. (1989). Non-axillary branching in the palms Eugeissona and Oncosperma (Arecaceae). Bot. J. Linn. Soc. 99, 347-363. doi 10.1111/j.1095-8339.1989.tb00407.x

Fletcher, L. C., Brand, U., Running, M. P., and Meyerowitz, E. M. (1999). Signaling of cell fate decisions by CLAVATA3 in Arabidopsis shoot meristems. Science 283, 1911-1914. doi: 10.1126/science.283.5409.1911

Floyd, S. K., and Bowman, J. L. (2007). The ancestral developmental tool kit of land plants. Int. J. Plant Sci. 168, 1-35. doi: 10.1086/509079

Fujita, H., Toyokura, K., Okada, K., and Kawaguchi, M. (2011). Reactiondiffusion pattern in shoot apical meristem of plants. PLOS ONE 6:e18243. doi: 10.1371/journal.pone.0018243

Goebel, K. (1918). Organographie der Pflanzen. II. Spezielle Organographie. H.2. Pteridophyten. 2nd Edn. Jena: G. Fischer Verlag.

Goebel, K. (1928). Organographie der Pflanzen. I. Allgemeine Organographie, 3rd Edn. Jena: G. Fischer Verlag.

Gola, E. (1996). Phyllotaxis diversity in Lycopodium clavatum L. and Lycopodium annotinum L. Acta Soc. Bot. Pol. 65, 235-247. doi: 10.5586/asbp.1996.036

Gola, E. M., and Jernstedt, J. A. (2011). Impermanency of initial cells in Huperzia lucidula (Huperziaceae) shoot apices. Int. J. Plant Sci. 172, 847-855. doi: $10.1086 / 660878$

Gorter, C. J. (1965). “Origin of fasciation,” in Encyclopaedia of Plant Physiology, Vol. 15, ed. W. Rhuland (New York: Springer), 330-351.

Gottlieb, J. E., and Steeves, T. A. (1961). Development of the bracken fern, Pteridium aquilinum (L.) Kuhn. III. Ontogenetic changes in the shoot apex and in the pattern of differentiation. Phytomorphology 11, 230-242.

Green, P. B. (1996). Expression of form and patterns in plants - a role for biophysical fields. Semin. Cell Dev. Biol. 7, 903-911. doi: 10.1006/scdb.1996.0110

Härtel, K. (1937). Studien an Vegetationspunkten einheimischer Lycopodien. Beitr. Biol. Pflanzen 25, 124-169.

Hagemann, W. (1980). Über den Verweigungsvorgang bei Psilotum und Selaginella mit Anmerkungen zum Begriff der Dichotomie. Plant Syst. Evol. 133, 181-197. doi: 10.1007/BF00984379

Hagemann, W., and Schulz, U. (1978). Wedelanlegung und Rhizomverzweigung bei einigen Gleicheniaceen. Bot. Jahrb. Syst. 99, 380-399.

Hallé, F., Oldeman, R. A. A., and Tomlinson, P. B. (1978). Tropical Trees and Forests. An Architectural Analysis. Berlin: Springer-Verlag. doi: 10.1007/978-3-64281190-6

Harrison, C. J., Corley, S. B., Moyan, E. C., Alexander, D. L., Scotland, R. W., and Langdale, J. A. (2005). Independent recruitment of a conserved developmental mechanism during leaf evolution. Nature 434, 509-514. doi: 10.1038 /nature 03410

Harrison, C. J., Rezvani, M., and Langdale, J. A. (2007). Growth from two transient apical initials in the meristem of Selaginella kraussiana. Development 134, 881889. doi: $10.1242 /$ dev.001008
Hébant-Mauri, R. (1993). Cauline meristems in leptosporangiate ferns: structure, lateral appendages, and branching. Can. J. Bot. 71, 1612-1624. doi: 10.1139/b93196

Heller, G., Lundén, K., Finlay, R. D., Asiegbu, F. O., and Elfstrand, M. (2012) Expression analysis of clavata1-like and nodulin21-like genes from Pinus sylvestris during ectomycorrhiza formation. Mycorrhiza 22, 271-277. doi: 10.1007/s00572011-0402-2

Imaichi, R. (2008). "Meristem organization and organ diversity," in Biology and Evolution of Ferns and Lycophytes, eds T. A. Ranker and C. H. Haufler (Cambridge: Cambridge University Press), 75-106.

Imaichi, R., and Kato, M. (1989). Developmental anatomy of the shoot apical cell, rhizophore and root of Selaginella uncinata. Bot. Mag. Tokyo 102, 369-380. doi: 10.1007/BF02488120

Imaichi, R., and Kato, M. (1991). Developmental study of branched rhizophores in three Selaginella species. Am. J. Bot. 78, 1694-1703. doi: 10.2307/24 44848

Iwamoto, A., Matsumura, Y., Ohba, H., Murata, J., and Imaichi, R. (2005). Development and structure of trichotomous branching in Edgeworthia chrysantha (Thymelaaeceae). Am. J. Bot. 92, 1350-1358. doi: 10.3732/ajb.92. 8.1350

Jernstedt, J. A., Cutter, E. G., and Lu, P. (1994). Independence of organogenesis and cell patterns in developing angle shoots of Selaginella martensii. Ann. Bot. 74, 343-355. doi: 10.1006/anbo.1994.1127

Jiang, K., and Feldman, L. J. (2005). Regulation of root apical meristem development. Annu. Rev. Cell Dev. Biol. 21, 485-509. doi: 10.1146/annurev.cellbio.21.122303.114753

Kaska, D. D., Myllylä, R., and Cooper, J. B. (1999). Auxin transport inhibitors act through ethylene to regulate dichotomous branching of lateral root meristems in pine. New Phytol. 142, 49-58. doi: 10.1046/j.1469-8137.1999.00379.x

Kato, M., and Imaichi, R. (1997). "Morphological diversity and evolution of vegetative organs in pteridophytes," in Evolution and Diversification of Land Plants, eds K. Iwatsuki and P. H. Raven (Berlin: Springer-Verlag), 27-43. doi: 10.1007/978-4-431-65918-1_2

Kenrick, K., and Crane, P. R. (1997). The Origin and Early Diversification of Land Plants: A Cladistic Study. Washington, DC: Smithsonian Institution Press.

Laajanen, K., Vuorinen, I., Salo, V., Juuti, J., and Raudaskoski, M. (2007). Cloning of Pinus sylvestris SCARECROW gene and its expression pattern in the pine root system, mycorrhiza and NPA-treated short roots. New Phytol. 175, 230-243. doi: 10.1111/j.1469-8137.2007.02102.x

Laux, T., Mayer, K. F. X., Berger, J., and Jürgens, G. (1996). The WUSCHEL gene is required for shoot and floral meristem integrity in Arabidopsis. Development 122, $87-96$.

Leyser, H. M. O., and Furner, I. J. (1992). Characterisation of three shoot apica meristem mutants of Arabidopsis thaliana. Development 116, 397-403.

Lian, G., Ding, Z., Wang, Q., Zhang, D., and Xu, J. (2014). Origins and evolution of WUSCHEL-Related homeobox protein family in plant kingdom. ScientificWorldJournal 2014:534140. doi: 10.1155/2014/534140

Lintilhac, P. M. (2014). The problem of morphogenesis:unscripted biophysical control systems in plants. Protoplasma 251, 25-36. doi: 10.1007/s00709-0130522-y

Lu, P., and Jernstedt, J. A. (1996). Rhizophore and root development in Selaginella martensii: meristem transitions and identity. Int. J. Plant Sci. 157, 180-194. doi: $10.1086 / 297337$

Lyndon, R. F. (1998). The Shoot Apical Meristem. Cambridge: Cambridge University Press.

Moss, B. (1967). The apical meristem of Fucus. New Phytol. 66, 67-74. doi: 10.1111/j.1469-8137.1967.tb05988.x

Mueller, R. J. (1982). Shoot morphology of the climbing fern Lygodium (Schizaeaceae): general organography, leaf initiation, and branching. Bot. Gaz. 143, 319-330. doi: 10.1086/337306

Nolan, J. R. (1969). Bifurcation of the stem apex in Asclepias syriaca. Am. J. Bot. 56, 603-609. doi: 10.2307/2440434

Øllgaard, B. (1979). Studies in Lycopodiaceae. II. The branching patterns and infrageneric groups of Lycopodium sensu lato. Am. Fern J. 69, 49-61. doi: $10.2307 / 1546896$

Øllgaard, B. (1990). "Lycopodiaceae," in The Families and Genera of Vascular Plants, Vol. I, Pteridophytes and Gymnosperms, eds K. U. Kramer and P. S. Green (Berlin: Springer), 31-39. doi: 10.1007/978-3-662-02604-5 10 
Oltmanns, F. (1889). Beiträge zur Kenntniss der Fucaceen. Cassel: T. Fischer Verlag.

Oltmanns, F. (1904). Morphologie und Biologie der Algen, Vol. 1. Jena: G. Fischer Verlag. doi: 10.5962/bhl.title.1660

Otręba, P., and Gola, E. M. (2011). Specific intercalary growth of rhizophores and roots in Selaginella kraussiana (Selaginellaceae) is related to unique dichotomous branching. Flora 206, 227-232. doi: 10.1016/j.flora.2010.07.001

Peterson, R. L., and Bonfante, P. (1994). Comparative structure of vesiculararbuscular mycorrizas and ectomycorrizas. Plant Soil 159, 79-88. doi: 10.1007/BF00000097

Piche, Y., Fortin, J. A., Peterson, R. L., and Posluszny, U. (1982). Ontogeny of dichotomizing apices in mycorrhizal short roots of Pinus strobus. Can. J. Bot. 60, 1523-1528. doi: 10.1139/b82-194

Raudaskoski, M., and Salo, V. (2008). Dichotomization of mycorrhizal and NPAtreated short roots in Pinus sylvestris. Plant Signal. Behav. 3, 113-115. doi: $10.4161 /$ psb.3.2.4972

Reddy, G. V. (2008). Live-imaging stem-cell homeostasis in the Arabidopsis shoot apex. Curr. Opin. Plant Biol. 11, 88-93. doi: 10.1016/j.pbi.2007.10.012

Reinhardt, D., Frenz, M., Mandel, T., and Kuhlemeier, C. (2003). Microsurgical and laser ablation analysis of interactions between the zones and layers of the tomato shoot apical meristem. Development 130, 4073-4083. doi: 10.1242/dev.00596

Reinhardt, D., Frenz, M., Mandel, T., and Kuhlemeier, C. (2004). Microsurgical and laser ablation analysis of leaf positioning and dorsoventral patterning in tomato. Development 132, 15-26. doi: 10.1242/dev.01544

Riding, R. T. (1976). True dichotomies in seedlings of Pinus radiata. Can. J. Bot. 54, 1020-1022. doi: 10.1139/b76-107

Robertson, N. F. (1954). Studies on the mycorrhiza of Pinus sylvestris. I. Pattern of development of mycorrhizal roots and its significance for experimental studies. New Phytol. 53, 253-283. doi: 10.1111/j.1469-8137.1954.tb05239.x

Roth, I. (1963). Histogenese der Luftsprosse und Bildung der "dichotomen" Verzweigungen von Psilotum nudum. Adv. Front. Plant Sci. 7, 157-180.

Rupp, L. A., Mudge, K. W., and Negm, F. B. (1989). Involvement of ethylene in ectomycorrhiza formation and dichotomous branching of roots of mugo pine seedlings. Can. J. Bot. 67, 477-482. doi: 10.1139/b89-067

Sanders, H. L., and Langdale, J. A. (2013). Conserved transport mechanisms but distinct auxin responses govern shoot patterning in Selaginella kraussiana. New Phytol. 198, 419-428. doi: 10.1111/nph.12183

Schoute, J. C. (1936). Fasciation and dichotomy. Rec. Trav. Bot. Néerl. 33, 204-213.

Schoute, J. C. (1938). "Morphology," in Manual of Pteridology, ed. F. Verdoorn (Hague: Martinus Nijhoff), 1-64.

Schüepp, O. (1966). Meristeme. Wachstum und Formbildung in den Teilungsgeweben höherer Pflanzen. Basel: Birkhäuser Verlag.

Schuster, R. M. (1984a). “Comparative anatomy and morphology of the Hepaticae," in New Manual of Bryology, Vol. 2, ed. R. M. Schuster (Nichinan: Hattori Botanical Laboratory), 760-891.

Schuster, R. M. (1984b). "Morphology, phylogeny and classification of the Anthocerotae," in New Manual of Bryology, Vol. 2, ed. R. M. Schuster (Nichinan: Hattori Botanical Laboratory), 1071-1092.

Snow, M., and Snow, R. (1931). Experiments on phyllotaxis. I. The effect of isolating a primordium. Philos. Trans. R. Soc. Lond. B Biol. Sci. 221, 1-43. doi: 10.1098/rstb.1932.0001

Steeves, T. A., and Sussex, I. M. (1989). Patterns in Plant Development. Cambridge: Cambridge University Press. doi: 10.1017/CBO9780511626227

Stes, E., Francis, I., Petry, I., Dolzblasz, A., Depuydt, S., and Vereecke, D. (2013). The leafy gall syndrome induced by Rhodococcus fascians. FEMS Microbiol. Lett. 342, 187-194. doi: 10.1111/1574-6968.12119

Suzuki, T., Inagaki, S., Nakajima, S., Akashi, T., Ohto, M., Kobayashi, M., et al. (2004). A novel Arabidopsis gene TONSOKU is required for proper cell arrangement in root and shoot apical meristems. Plant J. 38, 673-684. doi: 10.1111/j.1365-313X.2004.02074.x
Suzuki, T., Nakajima, S., Inagaki, S., Hirano-Nakakita, M., Matsuoka, K., Demura, T., et al. (2005). TONSOKU is expressed in S phase of the cell cycle and its defect delays cell cycle progression in Arabidopsis. Plant Cell Physiol. 46, 736-742. doi: $10.1093 / \mathrm{pcp} / \mathrm{pci082}$

Takiguchi, Y., Imaichi, R., and Kato, M. (1997). Cell division patterns in the apices of subterranean axis and aerial shoot of Psilotum nudum (Psilotaceae): morphological and phylogenetic implications for the subterranean axis. Am. J. Bot. 84, 588-596. doi: 10.2307/2445894

Tomlinson, P. B. (1970). Dichotomous branching in Flagellaria indica (Monocotyledones). Bot. J. Linn. Soc. 63(Suppl. 1), 1-14.

Tomlinson, P. B. (1971). The shoot apex and its dichotomous branching in the Nypa palm. Ann. Bot. 35, 865-879.

Tomlinson, P. B. (1979). Systematics and ecology of the Palmae. Annu. Rev. Ecol. Syst. 10, 85-107. doi: 10.1146/annurev.es.10.110179.000505

Tomlinson, P. B., and Posluszny, U. (1977). Features of the dichotomizing apices in Flagellaria indica (Monocotyledones). Am. J. Bot. 64, 1057-1065. doi: $10.2307 / 2442161$

Troll, W. (1937). Vergleichende Morphologie der höheren Pflanzen. T.2. Berlin: Gebrüder Borntraeger Verlag.

Troll, W. (1948). Allgemeine Botanik. Stuttgart: F. Enke Verlag.

van den Hoek, C., Mann, D. G., and Jahns, H. M. (1995). Algae. An Introduction to Phycology. Cambridge: Cambridge University Press.

Veit, B. (2009). Hormone mediated regulation of the shoot apical meristem. Plant Mol. Biol. 69, 397-408. doi: 10.1007/s11103-008-9396-3

von Guttenberg, H. (1966). Histogenese der Pteridophyten. Handbuch der Pflanzenanatomie. Bd. 7, T. 2. Berlin: Gebrüder Borntraeger.

Webster, T. R., and Steeves, T. A. (1964). Developmental morphology of the root of Selaginella kraussiana A. Br. and Selaginella wallacei Hieron. Can. J. Bot. 42, 1665-1676. doi: 10.1139/b64-165

Webster, T. R., and Steeves, T. A. (1967). Developmental morphology of the root of Selaginella martensii Spring. Can. J. Bot. 45, 395-404. doi: 10.1139/b67-039

White, R. A., and Turner, M. D. (1995). Anatomy and development of the fern sporophyte. Bot. Rev. 61, 281-305. doi: 10.1007/BF02912620

Wilcox, H. E. (1968). Morphological studies of the roots of red pine, Pinus resinosa. II. Fungal colonization of roots and the development of mycorrhizae. Am. J. Bot. 55, 686-700. doi: 10.2307/2440526

Wilson, E. R. L., and Field, R. J. (1984). Dichotomous branching in lateral roots of pine: types of forking in long and short secondary roots of Pinus radiata D. Don. New Phytol. 100, 87-92. doi: 10.1111/j.1469-8137.1985.tb02760.x

Yi, S.-Y., and Kato, M. (2001). Basal meristem and root development in Isoëtes asiatica and Isoëtes japonica. Int. J. Plant Sci. 162, 1225-1235. doi: 10.1086/322942

Zagórska-Marek, B. (1985). Phyllotactic patterns and transitions in Abies balsamea. Can. J. Bot. 63, 1844-1854. doi: 10.1139/b85-259

Conflict of Interest Statement: The author declares that the research was conducted in the absence of any commercial or financial relationships that could be construed as a potential conflict of interest.

Received: 06 February 2014; accepted: 21 May 2014; published online: 06 June 2014. Citation: Gola EM (2014) Dichotomous branching: the plant form and integrity upon the apical meristem bifurcation. Front. Plant Sci. 5:263. doi: 10.3389/fpls.2014.00263 This article was submitted to Plant Biophysics and Modeling, a section of the journal Frontiers in Plant Science.

Copyright (c) 2014 Gola. This is an open-access article distributed under the terms of the Creative Commons Attribution License (CC BY). The use, distribution or reproduction in other forums is permitted, provided the original author(s) or licensor are credited and that the original publication in this journal is cited, in accordance with accepted academic practice. No use, distribution or reproduction is permitted which does not comply with these terms. 